\title{
Analytical Strategies for the Determination of Deoxynivalenol and its Modified Forms in Beer: A Mini Review
}

\section{Analytické postupy stanovení deoxynivalenolu a jeho derivátů v pivu. Minireview}

\author{
Alexandra MALACHOVÁ, Elisabeth VARGA, Heidi Elisabeth SCHWARTZ-ZIMMERMANN, Franz BERTHILLER \\ Christian Doppler Laboratory for Mycotoxin Metabolism and Center for Analytical Chemistry, Department for Agrobiotechnology \\ (IFA-Tulln), University of Natural Resources and Life Sciences, Vienna (BOKU), Konrad Lorenz Str. 20 , 3430 Tulln, Austria \\ e-mail: alexandra.malachova@boku.ac.at
}

\author{
Reviewed Paper / Recenzovaný článek
}

\begin{abstract}
Malachová, A. - Varga, E. - Schwartz-Zimmermann, H. E. - Berthiller, F.: Analytical strategies for the determination of deoxynivalenol and its modified forms in beer: A mini review. Kvasny Prum. 61, 2015, No. 2, pp. 46-50

The aim of this review is to provide a brief overview of analytical methods used for the determination of deoxynivalenol and its modified forms deoxynivalenol-3- $\beta$-D-glucoside, 3-acetyl-deoxynivalenol and 15-acetyl-deoxynivalenol in beer. The analytical methods discussed involve gas chromatography coupled with flame ionization detection, electron capture detection and mass spectrometry as well as liquid chromatography hyphenated to ultra-violet detection and mass spectrometry. Special attention was paid to sample preparation. Immunochemical methods such as enzyme-linked immunosorbent assays (ELISAs) which represent efficient tools for fast screening of beer with no sample purification are also discussed.
\end{abstract}

Malachová, A. - Varga, E. - Schwartz-Zimmermann, H. E. - Berthiller, F.: Analytické postupy stanovení deoxynivalenolu a jeho derivátů v pivu. Minireview. Kvasny Prum. 61, 2015, č. 2, s. 46-50

Přehledové sdělení shrnuje stručný přehled analytických metod používaných pro stanovení deoxynivalenolu a jeho derivátů deoxynivalenol-3- $\beta$-D-glukosidu, 3-acetyldeoxynivalenolu a 15-acetyldeoxynivalenolu $v$ pivu. Teprve nedávno byly $v$ pivu identifikovány také oligoglykosidy deoxynivalenolu. Mezi analytickými metodami jsou uvedeny jak plynová chromatografie ve spojení s plamenoionizační detekcí, detekcí elektronového záchytu či hmotnostní spektrometrí, tak kapalinová chromatografie se spektrofotometrickou detekcí, a v neposlední řadě také kapalinová chromatografie ve spojení s hmotnostní spektrometrií. Diskuse je převážně zaměřena na prípravu vzorků před vlastní analýzou. Závěrečná část článku je věnována imunochemickým metodám. Nejrozšířenější imunochemickou metodou je tzv. ELISA (Enzyme-Linked Immunosorbent Assay), která představuje velice efektivní nástroj pro rychlou analýzu díky své jednoduchosti a přímé aplikaci tekutých vzorků bez předchozího přečištění.

Malachová, A. - Varga, E. - Schwartz-Zimmermann, H. E. - Berthiller, F.: Analytische Methoden für die Bestimmung von Deoxynivalenol und dessen modifizierten Formen in Bier. Kvasny Prum. 61, 2015, Nr. 2, S. 46-50

Dieser Review bietet einen kurzen Überblick über analytische Methoden für die Bestimmung von Deoxynivalenol und dessen modifizierten Formen Deoxynivalenol-3-ß-D-Glukosid, 3-Acetyl-Deoxynivalenol und 15-Acetyl-Deoxynivalenol in Bier. Die verwendeten Methoden umfassen Gaschromatografie in Verbindung mit Flammenionisationsdetektion, Elektroneneinfangdetektion und Massenspektrometrie, sowie Flüssigkeitschromatografie mit Spektrophotometrischer Detektion oder Massenspektrometrie. Besonderes Augenmerk wurde auf die Probenvorbereitung gelegt. Immunochemische Methoden, wie z.B. enzymgekoppelte Immunadsorptionstests (ELISA), die eine effektive Möglichkeit für das Screening von Bier ohne Probenaufreinigung darstellen, werden ebenfalls diskutiert.

Keywords: DON, deoxynivalenol-3-glucoside, masked mycotoxins, HPLC-MS, GC-MS, ELISA

Klíčová slova: DON, deoxynivalenol-3-glukosid, maskované mykotoxiny, HPLC-MS, GC-MS, ELISA

\section{INTRODUCTION}

Deoxynivalenol (DON) is a naturally occurring toxic secondary metabolite, predominantly produced by Fusarium species. The main producers of DON are F. graminearum and F. culmorum. They are important plant pathogens invading crops already on the field and the associated disease Fusarium head blight is characterized by pre-mature bleaching of wheat ears (EFSA, 2013). As a consequence, high economic losses due to lower yields of crops and a frequent DON contamination of wheat, barley, oat, rye and maize have been reported worldwide (Edwards, 2004). Fusarium infected grains pose a serious problem during food processing such as beer gushing or fermentation inhibition in bread making (Champeil et al., 2004). Moreover, DON was found to be stable under food processing conditions. Thus, it can be passed on from raw cereals into the final products (Bullerman and Bianchini, 2007; Hazel and Patel, 2004). The effects of food processing on mycotoxin levels in final products have become more important since the existence of so-called "masked mycotoxins" was confirmed. Masked mycotoxins are formed in plants as a defense against the parent toxin's deleterious effects. This detoxification process involves chemical modification of the parent toxin by a linkage to small polar molecules (sugars, amino acids, sulfate), leading to a decreased toxicity for plants. Masked mycotoxins are either stored in vacuoles or further incorporated (bound) into macromolecules (Berthiller et al., 2013). The major bio-transformation pathway of DON is the conjunction with glucose leading to formation of deoxynivalenol-3- $\beta$ D-glucoside (D3G) (Berthiller et al., 2009). So far, D3G has been found along with DON in wheat, maize, and barley, as reviewed by Berthiller et al. (2013). The first studies dealing with the effects of food processing on D3G revealed that alike DON, D3G can also be transferred into the final products, beer and bread. (Lancová et al., 2008, Kostelanská et al., 2011). Moreover, it was revealed that $D 3 G$ is likely to be further released from cell structures during malting and brewing because its levels in beer were increased compared to the used raw material (Lancová et al., 2008). Some recent survey studies on commercially available beers confirmed that D3G is a common contaminant in this beverage. The incidence of D3G was even higher than DON (Kostelanská et al., 2009; Varga et al., 2013). The average levels of D3G and DON in contaminated beer reported by Varga et al. (2013) were $9.5 \mu \mathrm{g} / \mathrm{l}$ and $13.6 \mu \mathrm{g} / \mathrm{l}$, respectively. Beside D3G also acetylated forms of DON, 3-acetyl-deoxynivalenol (3ADON) and 15-acetyl-deoxynivalenol (15ADON), might occur in beer. They are the fungal precursor of deoxynivalenol and are also formed as intermediates of the detoxification of DON in plants. However, their incidence in beer is very low (Kostelanská et al., 2009; Varga et al., 2013). Although DON belongs to the mycotoxins for which maximum levels are regulated by the European Commission (EC 1881/2006; EC 1126/2007), no limit for DON in beer has been established so far. Recently, it was revealed in various animal species that $3 A D O N$ and $15 A D O N$ are hydrolyzed to DON in vivo. Hence, their toxicity is similar to that of DON (reviewed by Wu et al., 2010). Therefore, the Joint FAO/WHO Expert Committee on Food Additives (JECFA) established a group provisional maximum tolerable daily intake (PMTDI) of $1 \mu \mathrm{g} / \mathrm{kg}$ body weight (b.w.) for the sum of DON, 3ADON and 15ADON (JECFA, 2011). The bioavailability of D3G is a subject of ongoing research. The latest studies on rats and pigs indicated that D3G partly contributes to the total DON intake (Nagl et al., 2012; Nagl et al., 2014). Authors of another study dealing with the bioavailability of masked mycotoxins confirmed that DON conjugates were effectively deconjugated by the human colonic microbiota releasing parent DON (Dall'Erta et al., 2013). Due to a high incidence of D3G 


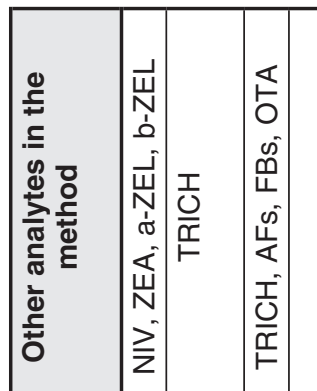

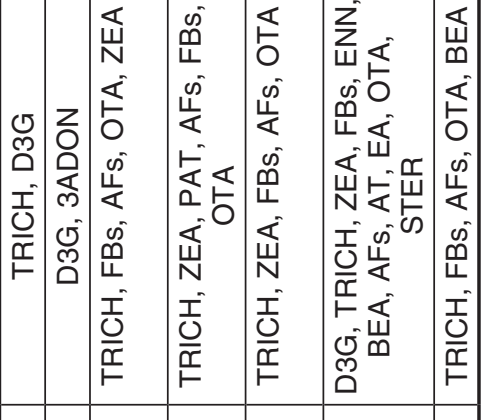

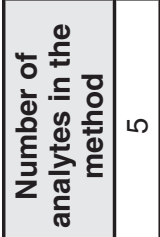

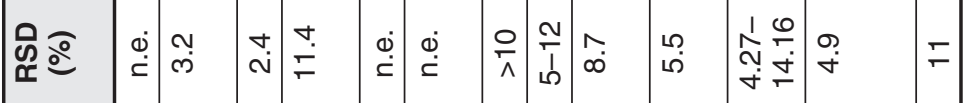

离

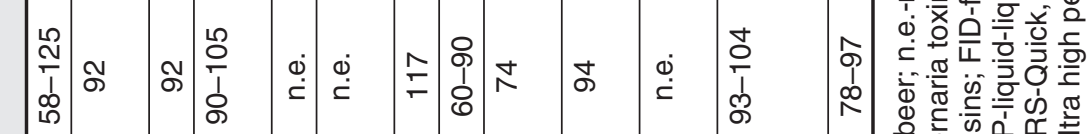

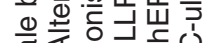

○。

๕ִ

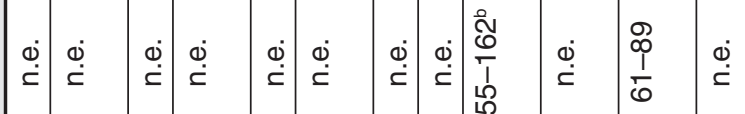

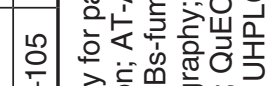

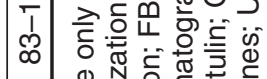

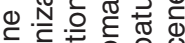

可言

ฉò

(1) ธิธ

:

व

흫ำ

है

$\frac{\Phi}{2}$

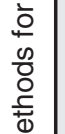

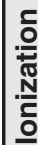

$\bar{\square} \quad \bar{\square}$

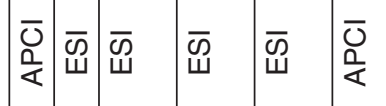

ळ

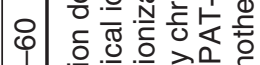

守

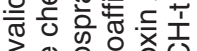

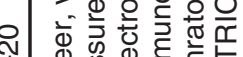

l.

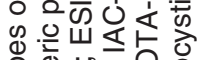
o

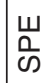

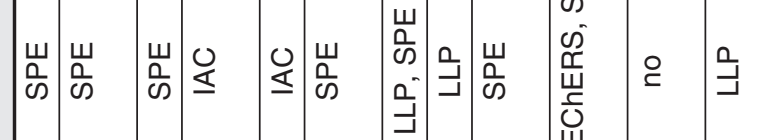

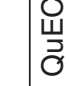

资

뜬

要

농

हั

क

ไె

$\frac{2}{1}$

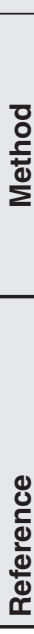

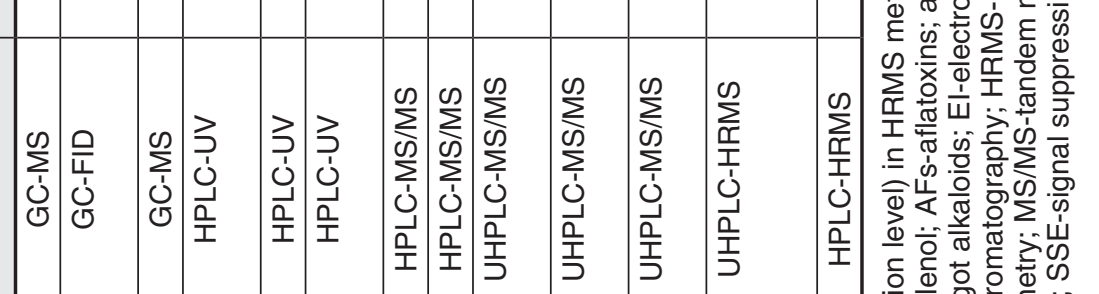

\begin{tabular}{|c|c|c|c|c|c|c|c|c|c|c|}
\hline 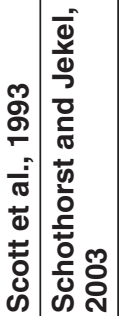 & 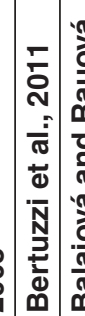 & 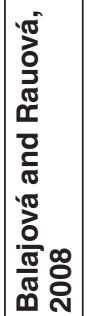 & 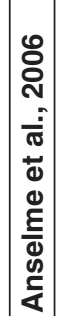 & 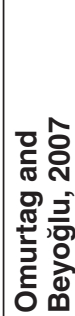 & & $\begin{array}{l} \pm \\
-0 \\
-\frac{0}{0} \\
\frac{0}{0}\end{array}$ & & ণิ & & 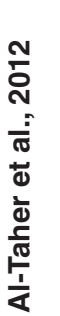 \\
\hline
\end{tabular}

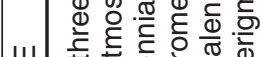

崩

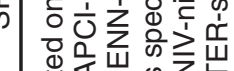

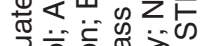

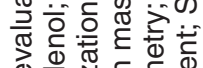

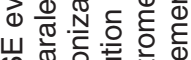
D.

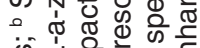
is

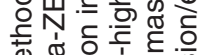
is

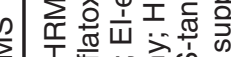

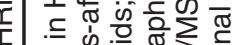

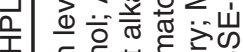

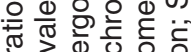

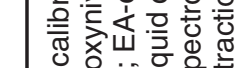

ᄃ

동

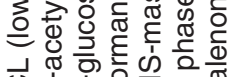

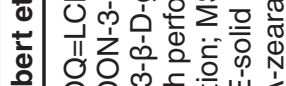

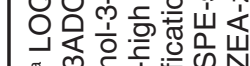

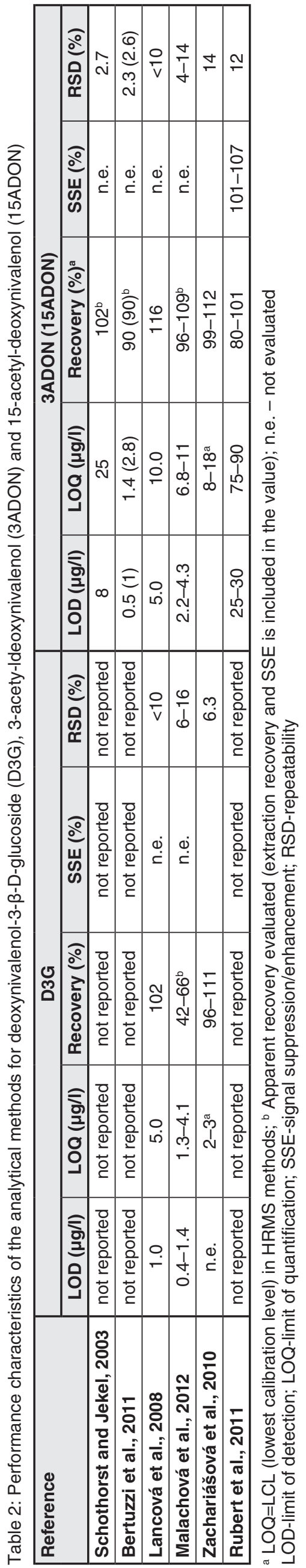


in cereals and cereal-based products and preliminary evidence about its bioavailability, the European Food Safety Authority (EFSA) has initiated the work on evaluation of human and animal risks related to DON, metabolites of DON and masked DON (EFSA, 2014). On this account, more occurrence data about DON and its conjugated forms are requested.

In this context this mini-review focuses on the analytical methods used for the determination of DON in beer with an emphasis on sample preparation techniques. In addition, analytical approaches for the determination of D3G, acetylated DONs and other masked DON-metabolites in beer are discussed.

\section{ANALYTICAL METHODS FOR THE DETERMINATION OF DON IN BEER}

In general, analytical approaches to determine DON in beer do not differ from procedures applied to cereals. Beer might be considered as an easy matrix for analysis in comparison to cereals because DON is already homogenously dissolved in liquid. Therefore, in principle, direct analysis of beer could be an option. However, several difficulties have to be taken into account in beer analysis. Beer is a complex matrix containing a wide range of low molecular compounds of various structural classes with different polarities which might interfere with the analysis of target compounds (Zachariášová et al., 2010). In addition, the levels of DON (and also other mycotoxins) in beer are approximately ten times lower compared to raw cereals. Therefore, a suitable analytical method has to be capable of detecting low levels ( $<5 \mu \mathrm{g} / \mathrm{l}$ for DON).

\subsection{Instrumental analytical methods}

Until recently, analytical methodology for the determination of DON in beer relied predominantly on gas chromatography (GC) coupled either with conventional detection such as electron capture detector (ECD) (Molto et al., 2000), flame ionization detector (FID) (Schothorst and Jekel, 2003) or mass spectrometry (MS) (Scott et al., 1993, Bertuzzi et al., 2011). Liquid chromatography hyphenated to spectrophotometric detection (LC-UV) has been used to a lesser extent (Anselme et al., 2006; Balajová and Rauová, 2008; Omurtag and Beyoğlu, 2007). Current trends in mycotoxin determination led to the development of fast, highly efficient and accurate analytical methods based on liquid chromatography coupled with mass spectrometry (HPLC-MS) (Romero-Gonzáles et al. 2009; Tamura et al., 2011; Malachová et al., 2012). An overview of some analytical methods used for the analysis of beer is provided in Table 1.

\subsubsection{Gas chromatography}

For several decades, GC used to be the first choice in trichothecene determination. However, polar, non-volatile compounds such as DON require a derivatization step prior to GC separation. In addition, extensive clean-up is important in order to remove matrix components reacting with the derivatization agent, interfering in final analysis or both. A two-step clean-up first on a cartridge with a hydrophilic stationary phase, then on a C18-cartridge was employed in a GC-MS method for the determination of DON along with nivalenol (NIV), zearalenone (ZEA), a-zearalenol and $\beta$-zearalenol in beer (Scott et al., 1993). In that study it was shown that heptafluorobutyric (HFB) derivatization resulted in a better sensitivity than derivatization with trimethylsilylation (TMS). The validated method was finally applied to the analysis of 50 beer samples. Due to the high sensitivity of the method, DON was detected in the range of $0.33 \mu \mathrm{g} / \mathrm{l}$ to $50.3 \mu \mathrm{g} / \mathrm{l}$. In 2003 , a combination of two multifunctional cartridges MycoSep ${ }^{\circledR 227}$ and MycoSep ${ }^{\circledR 2} 216$ instead of C18 was used for the purification of beer prior to TMS derivatization followed by GC-FID (Schothorst and Jekel, 2003). Likely due to poor sensitivity (limit of quantification - LOQ of $25 \mu \mathrm{g} / \mathrm{l}$ ), in only three out of 21 beers DON could be determined. In another study, multifunctional columns Trichothecene EP were used for beer purification and TMS-derivates were detected by GC-MS with a quantitation limit of $1.5 \mu \mathrm{g} / \mathrm{I}$ for DON (Bertuzzi et al., 2011). In 2000, a GC-ECD method achieving an LOQ of $2 \mu \mathrm{g} / \mathrm{l}$ for DON was used for the trichothecene occurrence survey of Argentinian beers (Molto et al., 2000). In that study, the sample preparation protocol of Scott et al. (1993) described above was employed. Concerning the modified forms of DON, an advantage of GC technique is the baseline separation of 3ADON and 15ADON which is tricky in reversed-phase LC. Some of the above described methods included also acetylated DONs, detailed method specifications for these conjugates are summarized in Table 2. For instance, 3ADON was included in the method by Schothorst and Jekel (2003). Likewise, Bertuzzi et al. (2011) included the acetylated DONs in a validated GC-MS method. However, neither $3 A D O N$ nor 15ADON were detected in any beer samples above the limit of detection (LOD) of $0.5 \mu \mathrm{g} / \mathrm{l}$ and $1.0 \mu \mathrm{g} / \mathrm{l}$, respectively.

\subsubsection{Liquid chromatography}

High performance liquid chromatography currently represents a dominating strategy in mycotoxin determination in general. Besides multi-analyte LC-MS methods covering groups of compounds with a wide range of physicochemical properties, single-analyte methods based on HPLC-UV were developed for DON determination in beer (Anselme et al., 2006; Balajová and Rauová, 2008; Omurtag and Beyoğlu, 2007). Unlike the GC-based methods, UV-detection does not require any derivatization, but needs to be performed at the absorption maximum of $220 \mathrm{~nm}$. The major drawback of HPLC-UV methods is the high background noise caused by matrix compounds. Thus, involvement of a specific purification step is necessary to achieve low limits of detection. The best option is the use of immunoaffinity chromatography (IAC). Beer is loaded directly (Balajová and Rauová, 2008) or after pre-concentration (Anselme et al., 2006) onto an IAC cartridge containing anti-DON antibodies. Matrix passes through and the analyte of interest is retained on the column. The cross-reactivity of the used antibodies determines whether only DON or also DON conjugates are retained. Following a washing step, DON is eluted using acetonitrile or methanol. Typical LOQs of IAC-HPLC-UV methods are below $10 \mu \mathrm{g} / \mathrm{l}$. A non-specific clean-up based on two-step purification using aluminacelite-charcoal and C18-cartridge cannot be recommended for beer analysis by HPLC-UV. The LOD of $625 \mu \mathrm{g} / \mathrm{l}$ achieved for DON is too high for detection of trace levels in beer (Omurtag and Beyoğlu, 2007).

High and ultra-high performance liquid chromatography (HPLC/UHPLC) hyphenated with various mass spectrometric (MS) detectors have become the most frequently used techniques in the field of mycotoxin analysis. So far, a few (U)HPLC methods coupled with tandem mass spectrometry (MS/MS) have been developed and validated for beer (Lancová et al., 2008; Romero-Gonzáles et al., 2009; Tamura et al., 2011; Malachová et al., 2012).

An HPLC-ion trap method with the ion trap operated in $\mathrm{MS}^{2}$ mode was developed and validated to study the transfer of DON, D3G, 3ADON and other trichothecenes from barley to malt and beer (Lancová et al., 2008). Furthermore, the method was applied to a survey involving the determination of these three analytes in 176 beers (Kostelanská et al., 2009). A simple sample preparation involving shaking with acetonitrile and Celite ${ }^{\circledR}$ and pre-concentration of purified beer by evaporation resulted in LOQs of $5 \mu \mathrm{g} / \mathrm{l}$ for both DON and its glycosylated form. Tamura et al. (2011) applied the QuEChERS technique for the analysis of beer using commercially available QuEChERS cartridges. The QuEChERS (Quick, Easy, Cheap, Effective, Rugged and Safe) method had originally been introduced for pesticide analysis, but has since then also been applied in many others fields. The method consists of extraction with acetonitrile in a disposable tube, followed by salting out and removal of water from the acetonitrile phase with $\mathrm{NaCl}$ and $\mathrm{MgSO}_{4}$. Purification is then achieved by dispersive solid phase extraction in which the extract is shaken with either a primary-secondary amine (PSA), silica gel alone, or with PSA plus C18 or graphite carbon black (GCB). In the method of Tamura et al. (2011), the QuEChERS extract was further cleaned through C18-cartridges. A UHPLC-triplequadrupole-MS (UHPLC-QqQ-MS) in selected reaction monitoring mode was used as a final analytical tool. The method was applied to a set of 24 Japanese beers in which DON was not detected at levels higher than $5 \mu \mathrm{g} / \mathrm{l}$. In another study, two types of SPE cartridges, Oasis HLB and C18, were tested for the purification of beer prior to the simultaneous determination of DON, type-A trichothecenes, aflatoxins, fumonisins, OTA and ZEA by UHPLC-QqQ-MS/MS (Romero-Gonzáles et al., 2009). In the development of multi-analyte methods, the sample preparation (extraction and clean-up) is a compromise to allow the determination of all involved analytes. Therefore, C18-cartridges were selected for further method development and validation due to better recoveries of aflatoxins. Although the validation was carried out for one pale beer only, the matrix effects were studied on three types of beer (non-alcoholic normal and special beer). No differences were observed when comparing normal and non-alcoholic beer, but a huge signal enhancement (overestimation of results) was revealed for special beer. Therefore, the use of matrix-matched calibration was recommended for analysis of different types of beer to overcome the matrix-induced underestimation or overestimation of results despite the inclusion of a purification step. Variable influences of matrix components in different types of beer were also confirmed by another study (Malachová et al., 2012). The HPLCMS/MS method for the determination of DON, D3G and 3ADON in six beer categories including pale, wheat, dark, bock, non-alcoholic beer and shandies was developed and in-house validated. The simplicity of the sample preparation method which consisted of degassing, precipitation of matrix components with cold acetonitrile and reconstitution of dried-down sample in solvent indicated that the analysis would be af- 
fected by matrix effects. Therefore, matrix matched calibrations based on spiked samples prepared from three beers of each category were used to compensate matrix effects. The method was applied to so far the largest survey study on beers where not only DON, but also D3G and 3ADON were monitored (Varga et al, 2013). Another option to cope with matrix-induced signal suppression/enhancement in LC-MS is a stable isotope dilution assay (SIDA). The approach is based on the addition of ${ }^{13} \mathrm{C}$-labelled internal standards to the samples prior to LC-MS analysis. Stable isotopically labelled standards exhibit identical chemical and physical properties as the target analytes, but they are not present in the naturally contaminated samples (reviewed by Rychlik and Assam, 2008). The first multi-mycotoxin method covering all mycotoxins regulated in maize based on the combination of 'dilute and shoot' approach and SIDA has been developed for maize (Varga et al., 2012). The application of the SIDA approach for beer and wine analysis was shown by Al-Taher et al. (2013). An aliquot of degassed beer (wine) was mixed with an appropriate amount of ${ }^{13} \mathrm{C}$-labelled standards and solvent mixture (acetonitrile:water, 30:70, v/v) prior to UHPLC-QqQ-MS/ MS analysis. The method was validated for beer and wine and applied to 76 beer samples. Indeed, the use of ${ }^{13} \mathrm{C}$-DON as an internal standard compensated the signal suppression for DON (Al-Taher et al., 2012). It is worth noticing that SIDA is an approach for compensation of matrix effects, not for their removal. Therefore, as neither a clean-up nor preconcentration of the samples was carried out, the method did not reach the $L O Q$ required for DON in beer analysis (Table 1). Concerning the application of SIDA in determination of conjugated forms of DON, only ${ }^{13} \mathrm{C}$-labelled $3 A D O N$ is commercially available so far.

High resolution MS (HRMS) enables a comprehensive profiling of a sample. High mass resolving power together with high mass accuracy plays an important role in the unbiased identification and reliable quantification of target analytes. In addition, retrospective data mining is possible by means of non-targeted search. The applicability of two types of HR mass spectrometers, the Time of Flight (TOF MS) and the Orbitrap (Orbitrap MS) for the determination of mycotoxins in beer was assessed (Zachariášová et al., 2010). To avoid contamination of the LC-MS system and to reduce matrix effects, the beer was purified by precipitation of matrix components with acetonitrile. The supernatant was then preconcentrated by evaporation and reconstituted in solvent. Such prepared spiked beer samples were used for the assessment of detection capability of TOF MS and Orbitrap MS. The TOF MS instrument operated at its maximum attainable mass resolving power (12,500 FWHM) was able to detected DON only at levels above $25 \mu \mathrm{g} / \mathrm{l}$. While using the 'ultra-high' mass resolving power of 100,000 FWHM, Orbitrap MS enabled detection of even $5 \mu \mathrm{g} / \mathrm{l}$. The final method was validated on UHPLC-Orbitrap MS. The target analytes were identified with a mass deviation less than $5 \mathrm{ppm}$. Moreover, acquisition of both positive and negative ions within a single run was possible when using 'high resolution' mode of 50,000 (FWHM). Validation data obtained for three different types of beer (pale lager, nonalcoholic and dark lager) revealed that both DON and D3G could be detected at levels $>3 \mu \mathrm{g} / \mathrm{l}$ for all beer types. Lowest calibration levels (LCL, better suited for HRMS than LOQ) for 3ADON were almost three times higher in pale lager and non-alcoholic beer $(8 \mu \mathrm{g} / \mathrm{ml}$ for both) and even eight times higher in dark lager beer compared to the LCL for DON and D3G (Zachariášová et al., 2010). Recently, the application of hybrid linear ion trap-HRMS to the determination of 18 mycotoxins in beer purified using Oasis HLB cartridges was studied by Rubert et al. (2011). Validation was performed on four types of beer (stout, red ale, ale and pale lager beer). Despite a mass resolving power of 100,000 FWHM, the LCLs for DON and 3ADON were too high for beer analysis (Table 1, Table 2).

A unique strategy of highly specific immunoaffinity based clean-up followed by UHPLC-HR (Orbitrap) MS was applied in the identification of novel DON oligoglycosides in malt and beer (Zachariášová et al., 2012). Two complementary approaches were used for structure elucidation: (i) MS monitoring of specific fragment ions formed upon in-source fragmentation of respective pseudomolecular ions and (ii) specific enzymatic hydrolysis reaction. It is supposed that DON oligoglycosides are released from starch after the enzymatic cleavage during malting and brewing. They occurred at trace levels compared to DON in beer (Zachariášová et al., 2012). Therefore, in order to achieve detectable levels for the subsequent structure elucidation, a specific pre-concentration of the samples was essential. First, a cascade of three DON immunoaffinity cartridges without cross-reactivity to D3G was used in order to remove DON. Then, DON oligoglycosides were trapped using the DON immunoaffinity cartridges with high cross-reactivity to D3G. Such a pre-concentrated sample was then analyzed. The separation of the analytes was performed by hydrophilic interaction liquid chromatography and reversed phase liquid chromatography. It was revealed that DON oligoglycosides containing up to four bound hexose units occurred in malt, beer and also other cereal-based products contaminated with DON. Due to lack of standards, quantification was not possible though.

\subsection{Immunological methods}

Enzyme-linked immunosorbent assays (ELISA) represent a group of methods for rapid screening of single analytes. Nowadays, several ELISA kits are commercially available for DON determination.

Two ELISA kits (both indirect competitive assays), Ridascreen ${ }^{\circledR}$ DON and EZ-Quant ${ }^{\circledR}$ High Sensitivity (HS) DON were used for extensive DON screening in 313 retail beers (Papadopoulou-Bouraoui et al., 2004). Beer samples were applied directly after degassing (cloudy beers were first filtered before analysis). All samples were analyzed in duplicates. Moreover, GC-MS was used as a confirmatory method for the analysis of 33 selected beer samples of different contamination levels to ensure the accuracy of results obtained by ELISA. In the first step, both ELISA kits were tested on DON spiked samples of pale and dark beer. The average recoveries of $111 \%$ and $134 \%$ for pale and dark beer, respectively, were obtained for Ridascreen ${ }^{\circledR}$ DON. Similar recovery values $(115 \%$ for pale beer, $138 \%$ for dark beer) were calculated for EZ-Quant ${ }^{\circledR}$ High Sensitivity (HS) DON. DON was found in $87 \%$ of tested beer samples $(4-56 \mu \mathrm{g} / \mathrm{l})$. The average contamination of the sample set was $13.5 \mu \mathrm{g} / \mathrm{l}$. A comparison of the results obtained by ELISA with those by GC-MS revealed that both ELISA kits systematically tended to overestimate the DON content likely due to the crossreactivity of antibodies (Papadopoulou-Bouraoui et al., 2004). Ridascreen $^{\circledR}$ DON was used also in one recently published DON survey of 99 beer samples in Poland. As in the latter study, beer was analyzed directly after degasing without any purification. DON was detected in all beers tested in a range of 6-70.2 $\mu \mathrm{g} / \mathrm{l}$ (Kuzdraliński et al., 2013).

A comprehensive assessment of the applicability of four commercially available ELISA kits for the analysis of DON and its conjugated forms in beer was performed in the study of Zachariášová et al., 2008. Altogether 20 different types of beer were analyzed by all four ELISA kits (Ridascreen $^{\circledR}$ DON, Veratox 5/5 DON ${ }^{\circledR}$, Deoxynivalenol EIA and AgraQuant ${ }^{\circledR}$ DON Assay 0.25/5.0) in duplicate. The obtained results were than compared to those determined by LC-MS/MS. The cross-reactivity of antibodies to DON conjugates was tested in aqueous solution and in beer spiked with D3G, 3ADON and 15ADON. For all tested kits, a crossreactivity to $D 3 G$ was documented. The highest response for D3G dissolved in water was observed in Ridascreen ${ }^{\circledR}$ DON, the lowest in Veratox $5 / 5 \mathrm{DON}^{\circledR}$. The cross-reactivity for 3ADON was more than three times higher compared to the values declared by the producers (Ridascreen ${ }^{\circledR}$ DON). The cross-reactivity for spiked beer samples was even higher than in the case of aqueous solutions of D3G, 3ADON, and 15ADON standards. The follow-up experiments with certified reference material of wheat which was analyzed with and without purification using Mycosep ${ }^{\circledR}$ 226 by means of ELISA as well as by a validated LC-MS/MS method revealed that not only DON conjugates, but also matrix contributes to the overestimation of DON results obtained by ELISA (Zachariášová et al., 2008). The issue of cross-reactivity of immunochemical methods for mycotoxin detection towards masked mycotoxins have been summarized in recently published review paper by Zachariášová et al. (2014).

\section{CONCLUSIONS}

Contamination of beer with DON and its conjugated forms poses a potential risk for human health. Indeed, beer can significantly contribute to the total daily intake of DON. For this reason, it is important to regularly monitor the levels of DON, D3G and acetylated DONs in this commodity. However, development of a rapid and simple analytical method for detection of these toxins at low levels in such a complex matrix as beer is not an easy task. As concerns the cost of analysis and the complexity of the method, ELISA represents an efficient and cheap analytical tool for rapid screening of total DON contamination in beer. However, the accuracy of the results has to be confirmed by validated methods based on GC-MS or LC-MS. Besides the high cost of equipment and time-consuming analysis, instrumental analytical methods (GC-MS, LC-MS/MS and LC-HRMS) require an experienced operator. To date, they represent the only techniques for accurate beer analysis.

\section{ACKNOWLEDGEMENT}

This work was supported by the Lower Austria Government and Ministry of Agriculture of the Czech Republic within the project QI111B044. The Austrian Federal Ministry of Science, Research and Economy, the Austrian National Foundation for Research, Technology and Development as well as BIOMIN Holding GmbH are gratefully acknowledged for funding the Christian Doppler Laboratory for Mycotoxin Metabolism. 


\section{REFERENCES}

Al-Taher, F., Banaszewski, K., Jackson, L., Zweigenbaum, J., Ryu, D., Cappozzo, J., 2013: Rapid Method for the Determination of Multiple Mycotoxins in Wines and Beers by LC-MS/MS Using a Stable Isotope Dilution Assay. J Agric Food Chem. 61(10): 2378-2384. DOI: 10.1021/jf304729f

Anselme, M., Tangni, E.K., Pussemier, L., Motte, J.-C., Van Hove, F., Schneider, Y.-J., Van Peteghem, C., Larondelle,Y., 2006: Comparison of ochratoxin A and deoxynivalenol in organically and conventionally produced beer sold on the Belgian market. Food Addit. Contam. 23(9): 910-918. DOI: 10.1080/02652030600743839

Balajová, E., Rauová, D., 2008: Application of a simple and rapid pre-treatment procedure in the high performance liquid chromatographic analysis of deoxynivalenol and zearalenone in beer. J. Food Nutr. Res. 47(4): 189-199.

Berthiller, F., Crews, C., Dall'Asta, C., De Saeger, S., Haesaert, G., Karlovsky, P., Oswald, I.P., Seefelder, W., Speijers, G., Stroka, J., 2013: Masked mycotoxins: A review. Mol. Nutr. Food Res. 57(1): 165-189. DOI: 10.1002/mnfr.201100764

Berthiller, F., Schuhmacher, R., Adam, G., Krska, R., 2009: Formation, determination and significance of masked and other conjugated mycotoxins. Anal. Bioanal. Chem. 395(5): 1243-1252. DOI: 10.1007/s00216-009-2874-x

Bertuzzi, T., Rastelli, S., Mulazzi, A., Donadini, G., Pietri, A., 2011: Mycotoxin occurrence in beer produced in several European countries. Food Control 22(12): 2059-2064. DOI: 10.1016/j.foodcont.2011.06.002

Bullerman, L.B., Bianchini, A., 2007: Stability of mycotoxins during food processing. Int. J. Food Microbiol. 119(1-2): 140-146. DOI: 10.1016/j.ijfoodmicro.2007.07.035

Champeil, A., Doré, T., Fourbet, J.F., 2004: Fusarium head blight: epidemiological origin of the effects of cultural practices on head blight attacks and the production of mycotoxins by Fusarium in wheat grains. Plant Sci. 166(6): 1389-1415. DOI: 10.1016/j.plantsci.2004.02.004

Dall'Erta, A., Cirlini, M., Dall'Asta, M., Del Rio, D., Galaverna, G., Dall'Asta, C., 2013: Masked Mycotoxins Are Effectively Hydrolyzed by Human Colonic Microbiota Releasing their Aglycones. Chem. Res. Toxicol. 26(3): 305-312. DOI: 10.1021/tx300438c

EC 1126/2007 [online]. http://eur-lex.europa.eu/legal-content/EN/TXT/ PDF/? uri=CELEX:32007R1126\&qid $=1422879405798 \&$ from $=E N$

EC 1881/2006 [online]. http://eur-lex-europa-eu/legal-content/EN/TXT/ PDF/?uri=CELEX:32006R18818\&qid $=14228794733958 \&$ from $=E N$

Edwards, S.G., 2004: Influence of agricultural practices on fusarium infection of cereals and subsequent contamination of grain by trichothecene mycotoxins. Toxicol. Lett. 153(1): 29-35. DOI: 10.1016/j.toxlet.2004.04.022

EFSA, 2013 [online] http://www.efsa.europa.eu/it/efsajournal/ doc/3379.pdf [ref. 2015-01-15]

EFSA, 2014 [online] http://registerofquestions.efsa.europa.eu/rawwar/mandateLoader?mandate=M-2013-0260 [ref. 2015-01-15]

Hazel, C.M., Patel, S., 2004: Influence of processing on trichothecene levels. Toxicol. Lett. 153(1): 51-59. DOI: 10.1016/j.toxlet.2004.04.040

JECFA, 2011 [online] http://www.who.int/foodsafety/chem/ summary72_rev.pdf [ref. 2015-01-15]

Kostelanská, M., Džuman, Z., Malachová, A., Capouchová, I., Prokinova, E., Skeriková, A., Hajšlová, J., 2011: Effects of Milling and Baking Technologies on Levels of Deoxynivalenol and its Masked Form Deoxynivalenol-3-Glucoside. J. Agric. Food Chem. 59(17): 9303-9312. DOI: 10.1021/jf202428f

Kostelanská, M., Hajšlová, J., Zachariášová, M., Malachová, A., Kalachová, K., Poustka, J., Fiala, J., Scott, P.M., Berthiller, F., Krska, R., 2009: Occurrence of Deoxynivalenol and Its Major Conjugate, Deoxynivalenol-3-Glucoside, in Beer and Some Brewing Intermediates. J Agric. Food Chem. 57(8): 3187-3194. DOI: 10.1021/jf803749u

Kuzdraliński, A., Solarska, E., Muszyńska, M., 2013: Deoxynivalenol and zearalenone occurrence in beers analysed by an enzyme-linked immunosorbent assay method. Food Control 29(1): 22-24. DOI: 10.1016/j.foodcont.2012.06.003

Lancová, K., Hajšlová, J., Poustka, J., Krplová, A., Zachariášová, M., Dostálek, P., Sachambula, L., 2008: Transfer of Fusarium mycotoxins and ,masked" deoxynivalenol (deoxynivalenol-3-glucoside) from field barley through malt to beer. Food Addit. Contam. Part A 25(6): 732-744. DOI: 10.1080/02652030701779625

Malachová, A., Varga, E., Schwartz, H., Krska, R., Berthiller, F., 2012: Development, validation and application of an LC-MS/MS based method for the determination of deoxynivalenol and its conjugates in different types of beer. World Mycotox. J 5(3): 261-270. DOI: 10.3920/WMJ2012.1425
Molto, G., Samar, M.M., Resnik, S., Martínez, E.J., Pacin, A., 2000: Occurrence of trichothecenes in Argentinean beer: a preliminary exposure assessment. Food Addit. Contam. 17(9): 809-813. DOI: 10.1080/026520300415363

Nagl, V., Schwartz, H., Krska, R., Moll, W.-D., Knasmüller, S., Ritzmann, M., Adam, G., Berthiller, F., 2012: Metabolism of the masked mycotoxin deoxynivalenol-3-glucoside in rats. Toxicol. Lett. 213(3): 367-373. 10.1016/j.toxlet.2012.07.024

Nagl, V., Woechtl, B., Schwartz-Zimmermann, H.E., Hennig-Pauka, I., Moll, W.-D., Adam, G., Berthiller, F., 2014: Metabolism of the masked mycotoxin deoxynivalenol-3-glucoside in pigs. Toxicol. Lett. 229(1): 190-197. DOI: 10.1016/j.toxlet.2014.06.032

Omurtag, G.Z., Beyoğlu, D., 2007: Occurrence of deoxynivalenol (vomitoxin) in beer in Turkey detected by HPLC. Food Control 18(2): 163-166. DOI: 10.1016/j.foodcont.2005.09.007

Papadopoulou-Bouraoui, A., Vrabcheva, T., Valzacchi, S., Stroka, J., Anklam, E., 2004: Screening survey of deoxynivalenol in beer from the European market by an enzyme-linked immunosorbent assay. Food Addit. Contam. 21(6): 607-617. DOI: 10.1080/02652030410001677745

Romero-Gonzáles, R., Vidal, J.L.M., Aguilera-Luiz, M.M., Frenich, A.G., 2009: Application of Conventional Solid-Phase Extraction for Multimycotoxin Analysis in Beers by Ultrahigh-Performance Liquid Chromatography-Tandem Mass Spectrometry. J Agric. Food Chem. 57(20): 9385-9392. DOI: 10.1021/jf903154a

Rubert, J., Mañes, J., James, K.J., Soler, C., 2011: Application of hybrid linear ion trap-high resolution mass spectrometry to the analysis of mycotoxins in beer. Food Addit. Contam. 28(10), 1438-1446. DOI: 10.1080/19440049.2011.595015

Rychlik, M., Asam, S., 2008: Stable isotope dilution assays in mycotoxin analysis. Anal Bioanal Chem 390(2): 617-628. DOI: 10.1007/ s00216-007-1717-x

Schothorst, R.C., Jekel, A.A., 2003: Determination of trichothecenes in beer by capillary gas chromatography with flame ionisation detection. Food Chem. 82(3): 475-479. DOI: 10.1016/S0308-8146(03)00117-1 Scott, P.M., Kanhere, S.R., Weber, D., 1993: Analysis of Canadian and imported beers for Fusarium mycotoxins by gas chromatography-mass spectrometry. Food Addit. Contam. 10(4), 381-389. DOI: 10.1080/02652039309374161

Tamura, M., Uyama, A., Mochizuki, N., 2001: Development of a Multi-mycotoxin Analysis in Beer-based Drinks by a Modified QuEChERS Method and Ultra-High-Performance Liquid Chromatography Coupled with Tandem Mass Spectrometry. Anal. Sci. 27(6): 629-635. DOI: 10.2116/analsci.27.629

Varga, E., Glauner, T., Köppen, R., Mayer, K., Sulyok, M., Schuhmacher, R., Krska, R., Berthiller, F., 2012: Stable isotope dilution assay for the accurate determination of mycotoxins in maize by UHPLC-MS/MS. Anal Bioanal Chem. 402(9):2675-2686. DOI: 10.1007/s00216-012-5757-5

Varga, E., Malachová, A., Schwartz, H., Krska, R., Berthiller, F., 2013: Survey of deoxynivalenol and its conjugates deoxynivalenol-3-glucoside and 3-acetyl-deoxynivalenol in 374 beer samples. Food Addit. Contam. Part A. 30(1): 137-146. DOI: 10.1080/19440049.2012.726745

Wu, Q., Dohnal, V., Huang, L., Kuča, K., Yuan, Z., 2010: Metabolic pathway of trichothecenes. Drug Metabol. Rev. 42(2): 250-267. DOI: 10.3109/03602530903125807

Zachariášová, M., Cuhra, P., Hajslova, J., 2014: Cross-reactivity of rapid immunochemical methods for mycotoxins detection towards metabolites and masked mycotoxins: the current state of knowledge. World Mycotox. J 7(4): 449-464. DOI: 10.3920/WMJ2014.1701

Zachariášová, M., Čajka, T., Godula, M., Malachová, M., Vepříková, Z., Hajšlová, J., 2010. Analysis of multiple mycotoxins in beer employing (ultra)-high-resolution mass spectrometry. Rapid Commun. Mass Spectrom. 24(22): 3357-3367. DOI: 10.1002/rcm.4746

Zachariášová, M., Hajšlová, J., Kostelanská, M., Poustka, J., Krplová, A., Cuhra, P., Hochel, I., 2008: Deoxynivalenol and its conjugates in beer: A critical assessment of data obtained by enzyme-linked immunosorbent assay and liquid chromatography coupled to tandem mass spectrometry. Anal. Chim. Acta 625(1): 77-86. DOI: 10.1016/j.aca.2008.07.014

Zachariášová, M., Václavíková, M., Lacina, O., Václavík, L., Hajšlová, J., 2012: Deoxynivalenol Oligoglycosides: New "Masked" Fusarium Toxins Occurring in Malt, Beer and Breadstuff. J. Agric. Food Chem. 60(36): 9280-9291. DOI: 10.1021/jf302069z

Manuscript received / Do redakce došlo: 6. 12.2014 Accepted for publication / Prijato k publikování: 19. 1. 2015 